\title{
Critical success factors when going global: New Zealand farming systems in South America
}

\author{
S.C. WILSON and J. S. ROWARTH \\ Waikato Management School, The University of Waikato, Private Bag 3240, Hamilton, New Zealand
}

jrowarth@waikato.ac.nz

\begin{abstract}
New Zealanders are being encouraged to find offshore investment opportunities where using a New Zealand farming system will give a competitive advantage. This analysis investigated three pasture-based dairying operations in South America. A comparison of the three cases against a framework for dairying success identified in the literature enabled critical success factors to be identified. These included infrastructure, human and animal capital, and an understanding of culture.
\end{abstract}

Keywords: Capital, culture, infrastructure, labour

\section{Introduction}

New Zealand farmers, individually and as corporates, have expanded operations overseas with differing degrees of success. This paper examines three companies that have taken New Zealand pasture-based dairying systems to South America: New Zealand Farming Systems Uruguay (NZFSU) which began in 2004; Manuka Farms Chile (MFC) which started operating in 2005; and Leite Verde which began in 1999 in Bahia, Brazil. The aim was to identify motivations and transferable lessons for future ventures. Insights were gained by reviewing the literature, anecdotal evidence, news releases and other information publicly available concerning the three enterprises. A framework was devised, and further information collected through interviews with key people in the industry. Industry leaders were able to add opinions and insights that are not currently found in the literature, giving validation to the findings in this report. Results are summarised in Table 1.

\section{Findings}

\section{Existing commercial agriculture}

Existing commercial agriculture is critical to modern dairy farming success. Dairy farms need existing infrastructure for support services, processing equipment, and day-to-day consumables. When NZFSU entered Uruguay in 2004, the country had some dairying infrastructure; however most farming was for beef (Price Waterhouse Coopers 2012). Within the 2500 dairy farms that did exist, only $20 \%$ had over
100 cows. In contrast, of 11798 New Zealand farms 97.7\% have over 100 cows (LIC \& Dairy NZ 2012). Due to the lack of scale NZFSU had infrastructure issues and lacked specialised equipment (Brook 2013).

Chile in 2005 had a stronger dairying tradition. There were productive regions mostly concentrated in the lakes area (Manuka S.A. 2009a), hence MFC had access to infrastructure. However, the pasturebased system needed additional services provided by New Zealanders operating in South America (Price Waterhouse Coopers 2012).

Agricultural growth was occurring in Brazil in 1999; however, this growth was not in the dairying sector (Price Waterhouse Coopers 2012). Leite Verde had to import specialised equipment, but they did have access to other agriculture support services e.g., tractors, irrigation, processing plant expertise (Kenworthy 2011). Leite Verde chose an isolated area that had a lot of potential but needed upfront investment (New Zealand Dairy Exporter 2009).

\section{Infrastructure}

The initial investment into the farms was a large upfront cost in South America. Most dairying regions did not have the roads, electricity, fences, water access, schools, and homes to support a productive dairy farm. All three of the enterprises studied experienced this issue in varying degrees. NZFSU had to develop roads and dams (Barry Brook, pers. comm. 18 January 2013); MFC had to develop roads, electricity, and housing on their Hacienda block (David Steele, pers. comm. 3 May 2013); and Leite Verde developed schools, roads, electricity, houses, and more in setting up their business (Wallace 2012).

Leite Verde faced the most significant challenge but was also the best informed. Simon Wallace, General Manager, spent eighteen months travelling in Brazil scoping the potential before identifying an isolated area in the Bahia region. Land prices and potential productivity outweighed the initial infrastructure cost (Wallace 2012). Realistic expectations for farm development allowed the Wallaces to build accurate forecasts and budgets. In contrast, MFC and NZFSU underestimated the cost and time it would take to develop the land and infrastructure, and have been 
failing to meet their initial forecasts (David Steele, pers. comm. 3 May 2013; Allan Freeth, pers. comm. 1 March 2013).

\section{Capital}

Investors often determine the level of control managers have over strategic decisions (Barry Brook, pers. comm. 18 January 2013). This was confirmed in the three cases examined. NZFSU initially sought New Zealand investors from both farming and finance industries, however, as the project grew and many key performance indicators were not met, NZFSU turned to international investors via share offerings (Brook 2013). NZFSU's land expansion drew financial resources away from farm development, delaying revenue generation and performance (Allan Freeth, pers. comm. 1 March 2013). Further, during the Global Financial Crisis the NZFSU share price fell and Olam International was able to purchase a significant shareholding at a discounted price (Barry Brook, pers. comm. 18 January 2013).

MFC sourced the initial investment funds from 14 established New Zealand farming families, many of whom are also part of the governance team. MFC also experienced higher than expected farm development costs, but was able to draw on New Zealand resources to fill the gap (David Steele, pers. comm. 3 May, 2013). MFC's ability to source funding within the New Zealand farming community led to the retention of control and family values.

Leite Verde was initially financed by the major shareholders: Wallaces, Bell, and Aguiar (New Zealand Dairy Exporter 2009). It was not until Leite Verde had established a profitable farming operation that the company went to external ventures for expansion capital (Wallace 2012). With outside investment, Leite Verde has been able to expand the farming operations by $66.7 \%$ and invest in a processing plant with its own supply chain. Three times Leite Verde undertook capital raising to finance their expansion (Wallace 2012). The delay in seeking outside investment meant Leite Verde could prove their operations were working and continue to operate the way they wanted to.

\section{Land}

Price and suitability are critical to return on investment (ROI) on land. Land has to be accessible with a suitable soil quality with a manageable climate (Price Waterhouse Coopers 2012). It also has to be affordable. Farmers are investing offshore because they see lower cost structures in comparison with New Zealand (New Zealand Government 2012). Parts of South America have similar climates and soils to New Zealand, however, the differences do require adaptations from the New Zealand farming system (Price Waterhouse
Coopers 2012). Uruguay is at similar latitude to Northland and potentially offered a similar environment for dairying. However, the weather patterns and terrain caused unforeseen problems (Brook 2013); the El Niño and La Niña weather patterns combined with flatter terrain caused unexpected droughts, higher winds and flooding over the course of the venture. MFC purchased land in an area of Chile similar to Southland (David Steele, pers. comm. 3 May 2013), and developed relatively unhindered by climatic events. In contrast, Leite Verde chose an area that was very different to New Zealand. The Bahia region is a sub-tropical savannah with diverse fauna and flora (Wallace 2012). The Leite Verde farming system relies on irrigation and tropical pastures and brought in expertise: Professor Adilson Aguiar, a local friend with connections to the agricultural and science industry, developed the pasture management plan that suited the region (Kenworthy 2011).

The enterprises studied all had farming operations that comprised different operational units. NZFSU has 16000 ha over three regions: central, NW and SE; the additional infrastructure associated with having farms spread across the entire country, and additional time to develop, hindered revenue generation and resulted in unexpectedly high operational costs (Allan Freeth pers. comm. 1 March, 2013). MFC has their main block the Hacienda Coihueco (19 529 ha), and twelve other farms (totalling 2766 ha) (Manuka S.A. 2009a). Leite Verde has five units each with their own circular irrigation pivots (56 ha each) (Wallace 2012).

\section{Pasture}

NZFSU had a strong background in pasture management because the company resulted from PGG Wrightson (PGGW) expanding their seed business into model farms then to dairy farms (Allan Freeth, pers. comm. 1 March 2013). PGGW had been operating in South America since 1999 and was having trouble implementing appropriate grazing systems of customers' farms because of the cultural and operational difference. NZFSU pursued the opportunity to increase production with a Whole Farm Management (WFM) system. Unfortunately, NZFSU experienced a one-inthirty-year drought in 2006/2007 and did not have the irrigation infrastructure to keep most pastures alive (Brook 2013). Production difficulties led to revenue generation issues and eventually to the Olam takeover. MFC has been able to manage the pastures using New Zealand specialists and complementing that with local knowledge. However, MFC relies on supplements to boost productivity and give the cows a balanced diet (David Steele, pers. comm. 3 May, 2013). Leite Verde uses $\mathrm{C} 4$ grasses like Tifton 85 Bermudagrass (Wallace 2012) and approximately $2.5 \mathrm{~kg} / \mathrm{cow} /$ day supplements (New Zealand Dairy Exporter 2009). 


\section{Cows}

The breed of animal used is important because it determines the milk yield, feed amounts, ability to graze, and adaption to climate. NZFSU and MFC used North American Holstein with a high milk yield and cross bred them with New Zealand Jersey Friesian Cross. The large Holstein, ideal for barns, total mixed rations, and high volume of milk, have experienced difficulties in adapting to grazing pasture, and condition score as well as fertility management have been challenging. As a consequence, milk solid production has not been as high as anticipated. Leite Verde cross bred current stock with Kiwi (Holstein $\times$ Jersey) crosses (Wallace 2012 ) in an attempt to achieve higher production in the grazing plus rations system.

\section{Governance}

The governance team for any organisations sets the organisational goals and determines what do to do in a changing environment (Caldwell \& Hansen 2010). Governance is especially important in an international environment where the rapidly changing environment and unfamiliar territory calls for an experienced board. NZFSU has a mixed board of half Uruguayans and half New Zealanders (Brook 2013). The mix was intended to ensure that the technical expertise was coupled with the environment, economic, and cultural expertise. Unfortunately, issues arose because the New Zealand members were setting what were considered to be unrealistic targets without effective communication with their Uruguayan counterparts (Barry Brook, pers. Comm. 18 January 2013). The issue was identified and the New Zealand governors became more hands-on.

MFC has a highly skilled dairying based board with representatives from major New Zealand agricompanies (Manuka S.A. 2009b). In addition, the executive team is a mix of experienced Chileans and New Zealanders. The CEO, Juan Carlos Peterson, is Chilean, which gives local knowledge at the top of the operational hierarchy (David Steele, pers. comm. 3 May, 2013). Leite Verde has governing individuals with New Zealand farming backgrounds, international

Table 1

Critical Success Factor Framework

\begin{tabular}{|c|c|c|c|}
\hline & $\begin{array}{l}\text { NZ Farming } \\
\text { Systems Uruguay }\end{array}$ & Manuka & Leite Verde \\
\hline Existing Agriculture & $\begin{array}{l}+ \text { Lots of agriculture potential } \\
\text { - Mainly beef, dairying concentrated } \\
\text { in the South West }\end{array}$ & + dairying tradition & $\begin{array}{l}\text { + Booming Ag industry } \\
\text { - Not in dairying }\end{array}$ \\
\hline Pasture & $\begin{array}{l}\text { + Deep rooted fescues were favoured } \\
\text { \& clover and lotus were available } \\
\text { - Irrigation used to reduce variation } \\
\text { in seasonal pasture growth }\end{array}$ & $\begin{array}{l}\text { Temperate climate } \\
\text { similar to Southland }\end{array}$ & $\begin{array}{l}\text { Sub-tropical climate } \\
+ \text { Tifton } 85, \text { sub- } \\
\text { tropical pastures }\end{array}$ \\
\hline Cows & $\begin{array}{l}\text { - North America Holsteins } \\
\text { + Cross-bred with NZ Jersey Friesian X } \\
\text { - Can't buy high quality heifers }\end{array}$ & $\begin{array}{l}\text { - American Holsteins } \\
\text { + Cross breeding with } \\
\text { NZ specimens } \\
\text { - Can't buy high quality heifers }\end{array}$ & $\begin{array}{l}\text { + Bos taurus } \\
+ \text { Mixed with Kiwi cross }\end{array}$ \\
\hline Capital & $\begin{array}{l}\text { Investors expected to be } \\
\text { NZers or NZ farmers } \\
\text { More than US } \$ 300 \text { mil over } \\
\text { the project was invested } \\
\text { Capital shift to land acquisition } \\
\text { from farm development } \\
\text { Delayed revenue generation } \\
\text { Delayed performance }\end{array}$ & $\begin{array}{l}\text { NZ investors include } \\
\text { wealthy farmers } \\
\text { Needed access to more capital }\end{array}$ & $\begin{array}{l}\text { Initial investment by } \\
\text { Wallaces and partners } \\
3 \text { capital raises }\end{array}$ \\
\hline Land & $\begin{array}{l}\text { Total land: } 16000 \text { ha } \\
\text { Early in project land } \\
\text { prices began to increase }\end{array}$ & $\begin{array}{l}\text { Total land: } 22295 \text { ha } \\
\text { Hacienda Coihueco = } 19529 \text { ha }\end{array}$ & $\begin{array}{l}\text { Total land: } 55000 \text { ha } \\
10 \% \text { used }\end{array}$ \\
\hline Irrigation & $\begin{array}{l}4000 \text { ha irrigated } \\
\text { (Forecast to } 7000 \text { ha) }\end{array}$ & & $5 \times 56$ ha pivots \\
\hline Staff & $\begin{array}{l}\text { Management team had experience } \\
\text { in Ag not in dairying } \\
\text { NZers didn't have Uruguayan } \\
\text { dairying experience } \\
\text { Hard to recruit NZers } \\
\text { Plan developed to have U operators } \\
\text { with NZ providing strategy }\end{array}$ & $\begin{array}{l}\text { Utilises local talent } \\
\text { Have difficulties retaining } \\
\text { NZ employees }\end{array}$ & $\begin{array}{l}\text { Simon Wallace } \\
\text { relocated to be GM }\end{array}$ \\
\hline Governance & NZers and $U$ & NZ investors and ag leaders & Brazilian partners \\
\hline
\end{tabular}


business practice and links to the Brazilian agriculture and research industries (Wallace 2012). MFC and Leite Verde have been able to negotiate changes in the environment and growth with governance support.

\section{Staff}

Staff engagement is necessary for consistent farm operations and improvement. This is doubly true when the farm is in an expansion phase (Allan Freeth, pers. comm. 1 March 2013). NZFSU operational staff are led by Juan Carlos Peterson, who is also an investor. Operational difficulties due to different understanding of urgency were sorted by improved communication (Barry Brook, pers. comm. 18 January, 2013). MFC has found it hard to retain New Zealand employees so is developing local talent. This provides both career and class promotion opportunities from labourer to manager in the highly segregated community. Benefits are that the staff are highly motivated to improve and are loyal to the company (David Steele, pers. comm. 3 May, 2013). Leite Verde advertises itself as a Brazilian firm with Kiwi leadership. The key New Zealand element is the General Manager and the governance; operational staff is almost completely Brazilian (Wallace 2012).

\section{Discussion}

Four key findings were identified and confirmed in this paper: the implementation of what has been considered to be the traditional all-grass New Zealand farming system offshore has not occurred; New Zealanders with relevant experience are essential for implementation; the right people are critical to success; and ventures need to reassess the time, risk, and profit involved in the project.

The implementation of "New Zealand" farming systems offshore has not occurred. It is argued that New Zealand farming systems are more than on-farm practices: they include all of the support services used to increase productivity. Pasture-based dairying requires a number of inputs that New Zealanders take for granted. Easy and timely access to infrastructure (e.g., energy and water) and support services (e.g., veterinarians and machinery experts) is essential to efficient farming systems. Due to the scarce nature of pasture-based farming system at medium to large scale there is a lack of established infrastructure and support services to supply the pasture-based operations. All three businesses studied have used the New Zealand farming system as a model and have had to adapt, resulting in lower productivity due to the limited support services. Adaptation, however, could be considered to be the New Zealand way...

New Zealanders with relevant experience are essential for implementation. Pasture based farming is something that New Zealand is uniquely good at; however, it requires a different mind-set to other farming styles (Price Waterhouse Coopers 2012). Operational performance takes longer to establish as the system requires inputs that require careful management and are built on the previous year's performance. Experience in building and maintaining the farming system is critical to success. Managers must be versed in the New Zealand system and so for the early years it is important to have a strong New Zealand influence in the operational team.

The right people are critical to success. This factor fits with the previous discussion point, but further to it, the everyday farming staff must be excellent. Farming in a new environment has unique challenges that need expertise to handle. In addition, the amount of time required to convert a farm is immense; therefore, staff must be self-motivated, committed, and have the knowledge to build a profitable venture.

Ventures need to reassess the time, risk, and profit involved in the project. Across the three case studies, getting the venture up and running has taken more time and money than forecast. In addition, there are many risk factors that are not identifiable until one is familiar with the environment. Therefore, as a general rule "double the time, triple the risk, and halve the profit"; if it still looks profitable you should pursue the venture (Bill Falconer, pers. comm. 4 February 2013).

\section{ACKNOWLEDGEMENTS}

Barry Brook from NZFSU, Bill Falconer from Primary Growth Partnership, David Steele, Forsyth Barr, and Board of Directors for Manuka Farms Chile, and Allan Freeth ex-Wrightson, for taking time to provide valuable information to add to the case studies; Frank Scrimgeour for comment.

\section{REFERENCES}

Brook, B. 2013. The importance of whole farm management - a case study of NZ Farming Systems Uruguay. Wellington: New Zealand Institute of Primary Industries Management Journal. 17(2): 7-13.

Caldwell, C.; Hansen, M.H. 2010. Trustworthiness, governance, and wealth creation. Journal of Business Ethics 97: DOI 10.1007/s10551-010-0503-4.

Kenworthy, A. 2011, August 1. Leitissimo strikes dairy gold in Brazil. Idealog in the Ideas Business. http://www.idealog.co.nz/magazine/34/milky-way Accessed November 2012. 
LIC \& DairyNZ. 2012. New Zealand dairy statistics 2011-2012. Hamilton: LIC.

Manuka S.A. 2009a. Manuka our farms. Retrieved from Manuka: www.manuka.cl Accessed December 2012.

Manuka S.A. 2009b. Manuka - executive structure. Retrieved from Manuka: www.manuka.cl Accessed December 2012.

New Zealand Dairy Exporter. 2009, May 1. Brazil yields El Dorado of milk. www.dairyexporter.co.nz Accessed December 2012
New Zealand Government. 2012. The business growth agenda progress reports: building export markets. www.mbie.govt.nz Accessed May 2013.

Price Waterhouse Coopers. 2012. New Zealand agribusiness South America and China: opportunities and recommendations. www.nzte.govt.nz. Accessed May 2013.

Wallace, S. 2012, October 22. Dairying in Brazil. (K. Hill, Interviewer). Sourced From: http://www. radionz.co.nz/national/programmes/saturday/ audio/2500851/simon-wallace-dairying-in-brazil 
